\title{
NEW SPECIES OF THE GENUS ALTENSTEINIA (ORCHIDACEAE, SPIRANTHOIDEAE) FROM COLOMBIA
}

\author{
SŁawomir NowaK ${ }^{1}$, Dariusz L. Szlachetko \& JoAnna Mytnik-EjSmont
}

\begin{abstract}
A new species of Altensteinia Kunth, probably endemic to the Colombian Andes, is described, illustrated and discussed, with notes on its habitat and altitude. A dichotomous key for determination of Altensteinia species in Colombia is provided.
\end{abstract}

Key words: $A a$, Andes, Myrosmodes, new species, taxonomy

Stawomir Nowak, Dariusz L. Szlachetko \& Joanna Mytnik-Ejsmont, Department of Plant Taxonomy and Nature Conservation, University of Gdańsk, Wita Stwosza 59,80-308 Gdańsk, Poland; e-mail: slawomir.nowak@ug.edu.pl

\section{INTRODUCTION}

The orchid genus Altensteinia was described by Kunth in 1816. Aa Rchb. f. and Myrosmodes Rchb. f., were proposed by Reichenbach in 1854. Twenty-four years later, Reichenbach (1878) combined all three genera under the priority name Altensteinia. Aa was revalidated by Schlechter (1912). Later taxonomists classified the three genera differently. For example, Schweinfurth (1958) recognized only Altensteinia as a good genus but Garay (1978) kept all three genera separate. Molecular analyses by Álvarez-Molina and Cameron (2009) indicate that Altensteinia is closely related to both Aa and Myrosmodes; hence the unclear classification of those three genera, as well seen in Pridgeon et al. (2003) where Altensteinia is illustrated by $A$. matthewsii Rchb. f., a species possessing all characters of $\mathrm{Aa}$. In this paper we follow the generic concept of the three taxa proposed by Garay (1978).

The species of Altensteinia are caespitose plants with clusters of long fibrous roots. The stem is erect, usually robust, and enclothed with herbaceous sheaths, the lower 1 or 2 of which are often leafy. The leaves are gathered in a conspicuous basal rosette; the blade is shortly petiolate to subsessile, ovate to narrowly ligulate, with an acute to

\footnotetext{
1 Corresponding author
}

acuminate apex. The inflorescence is terminal, erect and racemose, with many nonresupinate flowers. The rachis is glabrous or sometimes pubescent. The herbaceous floral bracts are prominent and as long as or shorter than the ovary. The flowers usually are greenish, yellowish, or intermediate between green and yellow. The sepals are dissimilar and free, spreading or reflexed, with a pubescent external surface. The petals are linear, free and reflexed, longer and distinctly narrower than the sepals. The lip is concave, flaring to galeate in shape, with a cuneate sessile or clawed base. The column part is obscure and footless. The anther is erect, oblong and dorsiventrally compressed, with two parallel chambers. The soft and powdery pollinia are two but bipartite, oblong to narrowly ovoid. Caudiculae are absent. A distinct dorsal clinandrium is formed by staminodes. The stigma is large, flat and three-lobed, confluent, and elliptic to oval. The rostellum is truncate or rounded, the viscidium single, detachable, cellular and multilayered, and elliptic to crescent-like (Szlachetko \& Rutkowski 2000).

Altensteinia is a geophyte genus with ca 10 species native to the Andes of South America. All species of the genus grow as terrestrials, generally on steep rocky and mossy slopes, grassy slopes, damp meadows, thickets and along roadsides, 

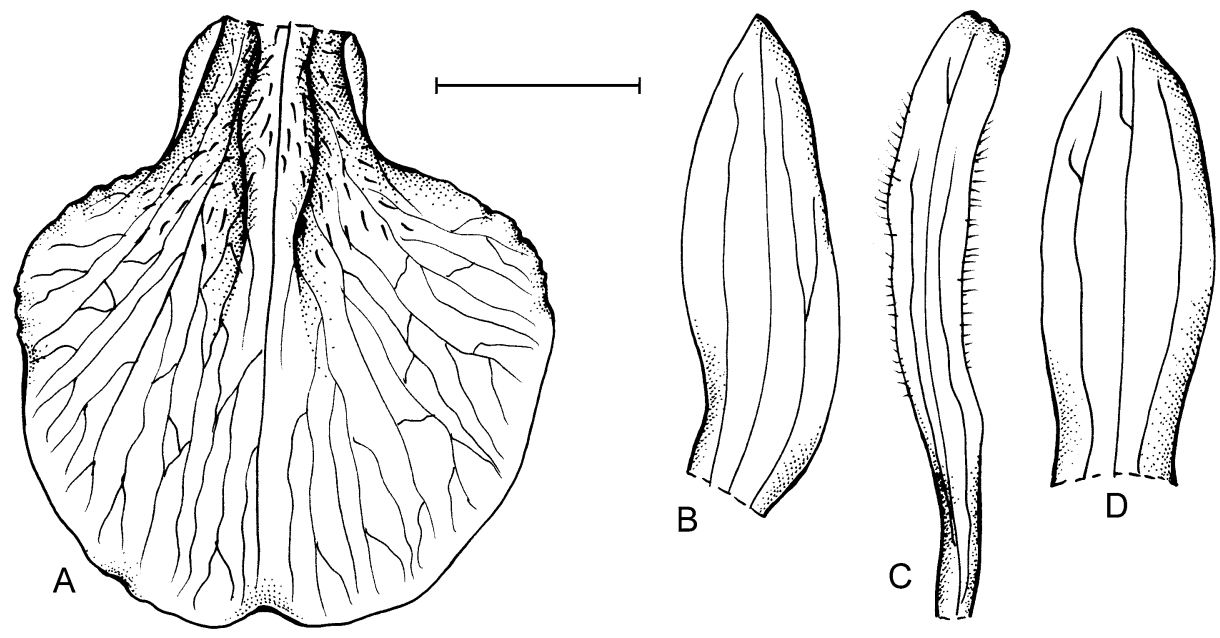

Fig. 1. Altensteinia cundinamarcae S. Nowak, Szlach. \& Mytnik, sp. nov. A - lip, B - lateral sepal, C - petal, D - dorsal sepal. Drawn by J. Mytnik-Ejsmont from holotype. Scale bar $=5 \mathrm{~mm}$.

usually in full sun or semishade at higher altitudes above $1800 \mathrm{~m}$ a.s.l. (Pridgeon et al. 2003).

During an examination of herbarium materials of spiranthoid orchids housed in Colombian herbaria (COL, FMB; acronyms of herbaria follow Thiers 2014) we came across materials of Altensteinia which did not fit the descriptions of any species known so far. Here we describe it as a new species. We examined specimens (including types) of other species of Altensteinia occurring in Colombia in the Royal Botanic Gardens, Kew (K), Naturhistorisches Museum Wien (W), Muséum National d'Histoire Naturelle in Paris (P), Real Jardín Botánico in Madrid (MA), Missouri Botanical Garden (MO), and Biozentrum KleinFlottbek in Hamburg (HBG).

\section{DESCRIPTION OF THE NEW SPECIES}

Altensteinia cundinamarcae S. Nowak, Szlach. \& Mytnik, sp. nov.

Fig. 1

Altensteinia cundinamarcae is unusual among all other species of the genus in having a suborbicular-quadrate lip with entire margins. Unlike the closely related $A$. virescens Lindl., the new entity has linear-falcate, truncate petals, and floral bracts with glandular margins.
TYPE: COLOMBIA, Cundinamarca, Bogota, Loc. 5, Usme, sector del Embalse de Chisaca, Vereda El Hato, alt. $3000-3200 \mathrm{~m}, 4^{\circ} 20^{\prime} \mathrm{N}, 7^{\circ} 15^{\prime} \mathrm{W}, 18$ Aug. 2005 , Y. Figueroa C. \& L. Pinzon 656 (Holotype: COL; ISOTYPE: FMB).

Plants 30-42 cm tall, erect, stout, almost glabrous, below and within inflorescence sparsely glandular. Leaves 6, 5 lower gathered in basal rosette, the upper one cauline; up to $18 \mathrm{~cm}$ long and $2.5 \mathrm{~cm}$ wide, oblong-lanceolate to linear-lanceolate, acute. Above the uppermost leaf 4 cauline bracts. Inflorescence 10-12 cm long, loosely severalflowered. Flowers medium-sized, non-resupinate. Floral bracts 13-15 mm long, ovate, acute, glandular-ciliate along margins only. Ovary 10-12 mm long, subsessile, densely glandular. Sepals densely glandular on outer surface exteriorly. Dorsal sepal 10-12 mm long, 4.0-4.5 mm wide, ligulate to oblong-lanceolate, obtuse, slightly concave in center, 3-nerved. Petals $\mathrm{ca} 15 \mathrm{~mm}$ long, $2 \mathrm{~mm}$ wide, linear-ligulate, truncate at apex, sigmoid, margins densely ciliate above base and below apex, nerves 3. Lateral sepals $12-14 \mathrm{~mm}$ long, $4.5 \mathrm{~mm}$ wide, oblong-lanceolate to ligulate-lanceolate, falcate above base, subobtuse, 3-nerved. Lip 15-17 mm long in total, slightly thickened in center; claw $3 \mathrm{~mm}$ long and wide, densely pubescent on inner surface, with no auricles; lamina up to $13 \mathrm{~mm}$ long 
and $17 \mathrm{~mm}$ wide, quadrate-suborbicular, concave in center, margins entire, apex slightly incised. Gynostemium up to $6 \mathrm{~mm}$ long, typical for the genus.

ETYMOLOGY. In reference to the place of origin of the original material, Cundinamarca Department in Colombia.

DisTRIBUTION. Known only from the type locality.

Notes. Altensteinia cundinamarcae undoubtedly is related to $A$. virescens Lindl., from which it differs by several features, the most striking of which is lip morphology. Unlike all other members of Altensteinia, in A. cundinamarcae and $A$. virescens the lip margins are not fimbriate, making them easily separable. The lip margin of the new entity is entire, whereas in $A$. virescens it is finely erose. Additionally, the lip of $A$. cundinamarcae is quadrate-suborbicular, densely pubescent on the inner surface, and without any basal auricles. The lip of $A$. virescens is spathulate, glabrous on the inner surface, and with prominent auricles at the base of the claw. The petals of $A$. cundinamarcae are apically truncate and the floral bracts are glandular along the margins. The petals of $A$. virescens are acute and the floral bracts are glabrous.

The newly proposed species was collected in Colombia near the Bogota suburbs, a few kilometers north of Sumapaz National Park. The small population of plants representing the new species grows at high altitude above the tree line in the $\mathrm{Su}-$ mapaz Páramo region, which is famous for having the most diverse flora of the Eastern Cordillera; it is also the world's largest páramo ecosystem, with a substantial number of endemic taxa (Cleef 1981; Davis et al. 1997), designated, along with the Andes mountains, as a tropical Andes biodiversity hotspot (Myers 1988; Myers et al. 2000; Mittermeier et al. 2004). The tropical Andes and the Sumapaz Páramo region are seriously endangered by logging, unsustainable agriculture, burning and cattle-grazing on the páramo (Davis et al. 1997; Mittermeier et al. 2004).

\section{Key to The COLOMbian SPECIES OF ALTENSTEINIA}

1. Lip margin fimbriate ............... 2

1. Lip margin erose or entire............ 3

2. Petals obtuse, with ciliolate margins; floral bracts pubescent ........... A. fimbriata Kunth

2. Petals truncate, with denticulate margins; floral bracts sparsely glandular A. sceptrum Rchb. f.

3. Petals acute; floral bracts glabrous . .......... .................... virescens Lindl. 3. Petals truncate; floral bracts glandular along mar-

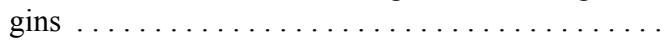
.. A. cundinamarcae S. Nowak, Szlach. \& Mytnik

Acknowledgements. We thank Dr. Carlos Parra, Curator of COL, and also Dr. Ricarda Riina (MA), Dr. André Schuiteman (K), Dr. Marc Pignal (P) and Dr. Ernst Vitek (W) for their kind hospitality and assistance during our visits to the herbaria, the curators of MO and HBG for making specimens available on loan, and the anonymous reviewers for helpful remarks on the manuscript. This study is part of a project supported by a grant from the Polish Ministry of Science and Higher Education (3930/PO1/2007/33) and the SYNTHESYS program (AT-TAF-3068, FR-TAF-3073, ES-TAF-3937).

\section{REFERENCES}

Álvarez-Molina A. \& Cameron K. M. 2009. Molecular phylogenetics of Prescottiinae s.l. and their close allies (Orchidaceae, Cranichideae) inferred from plastid and nuclear ribosomal DNA sequences. Amer. J. Bot. 96: 1020-1040.

Cleef A. M. 1981. The vegetation of the paramos of the Colombian Cordillera Oriental. University of Amsterdam, The Netherlands.

Davis S. D., Heywood V. H. , Herrera-MacBryde O., VillaLobos J. \& Hamilton A. (eds) 1997. Centres of plant diversity: a guide and strategy for their conservation. 3: The Americas. IUCN Publications Unit, Cambridge, England.

Garay L. A. 1978. Orchidaceae. Cypripedioideae Orchidoideae Neottioideae. In: G. Harling \& B. Sparre (eds), Flora of Ecuador 9: 1-305. University of Göteborg, Stockholm, Sweden.

Kunth C. S. 1816. Altensteinia. In: A. von Humboldt, A. Bonpland \& C. S. Kunth (eds), Nova genera et species plantarum, p. 332. Lutetiae, Parisiorum.

Mittermeier R. A., Robles Gil P., Hoffman M., Pilgrim J., Brooks T., Mittermeier C. G., Lamoreux J. \& DA FonSECA G. A. B. 2004. Hotspots revisited: earth's biologically 
richest and most threatened terrestrial ecoregions. CEMEX, Mexico City.

Myers N. 1988. Threatened biotas: "Hotspots" in tropical forests. The Environmentalist 8: 1-20.

Myers N., Mittermeier R. A., Mittermeier C. G., DA FonSECA G. A. B. \& Kent J. 2000. Biodiversity hotspots for conservation priorities. Nature 403: 853-858.

Pridgeon A. M., Cribb P. J., Chase M. W. \& Rasmussen F. N. 2003. Genera Orchidacearum. 3. Orchidoideae (Part two), Vanilloideae. Oxford University Press, New York, USA.

Reichenbach H. G. 1854. Altensteinia, Aa and Myrosmodes. Xenia Orchid. 1: 18.

Reichenbach H. G. 1878. Orchideae Mandonianae. Xenia Orchid. 3: 17-19.
SCHLeChter R. 1912. Die Orchideen Gattungen Altensteinia HBK, Aa Rchb. f. und Myrosmodes Rchb.f. Repert. Spec. Nov. Regni Veg. 11: 147-150.

Schweinfurth C. 1958. Orchids of Peru. Fieldiana, Bot. 30(1): 1-260.

Szlachetko D. L. \& Rutkowski P. 2000. Gynostemia Orchidalium. 1. Apostasiaceae, Cypripediaceae, Orchidaceae (Thelymitroideae to Vanilloideae). Acta Bot. Fenn. 169: 234 .

ThIERs B. 2014. Index Herbariorum: A global directory of public herbaria and associated staff. New York Botanical Garden's Virtual Herbarium. [April 2014]. http://sweetgum.nybg.org/ih.

Received 1 March 2014 